\title{
Collaborative and Individual Writing Strategies for EFL Writing Instruction: Outcomes and Perceptions
}

\author{
Ika Rama Suhandra, M. L. Manda, Ria Rosdiana Jubhari, Harlinah Sahib \\ Faculty of Cultural Studies, Hasanuddin University, Indonesia
}

\begin{abstract}
This study investigated 1) whether or not the collaborative writing strategy had a positive influence towards students' writing achievement than the students who wrote individually, and 2) the students' perceptions concerning the use of the collaborative writing strategy. The research was conducted by applying the mixed-method design. The subjects of the study were 64 students of Mataram State Islamic University which distributed randomly in two groups; experimental and control groups. Data were collected using the relevant research instruments such as: essay writing test and questionnaire. The data were analyzed quantitatively and qualitatively. Two major findings emerged. First, it revealed that there was a difference of the experimental and control groups' mean scores of their posttest. The experimental group's mean score $(M=7.14)(S D=0.57)$ was greater than that of control group's mean score (6.45) $(\mathrm{SD}=\mathbf{0 . 5 3})$. Seen from its independent sample test, it also unveiled that their sig. (2-tailed) (0.00) was lower than (0.05). This statistical evidence exhibited that there was a significant difference between the students who employed collaborative writing strategy than those who did not employ it. Second, all students' responses were positive towards the application of collaborative writing strategy as it increased students' motivation and confidence, reduced stress, gave new horizon on the way of how students to write, shared mutual feedback, gave a good attitude to respect each other, and knew others characters.
\end{abstract}

Keywords: Collaborative; writing; individual; strategy

\section{INTRODUCTION}

$\mathrm{T}$ the shift from teacher-centered to learner-centered approach has a wide influence on educational practice. The "learner-centered approach" in educational practice focuses the attention on the individual needs of learners that are believed to be important to consider. In the ELT context, Harmer (2003) contends that in recent years, under the influence of humanistic and communicative theories, great emphasis has been placed on 'learner-centered' teaching, that is teaching which makes the learners' needs and experiences central to the educational process. In line with sentiments raised by Harmer (2003), Richards \& Renandya (2002) assert that learners are seen to learn in different ways and to have different needs and interests. Language programs and the teachers who work in them should, therefore, set out to provide learners with effective learning strategies, to assist learners in identifying their own preferred ways of learning. The effective learning strategy then should be provided in all aspects of teaching, especially in language teaching with the main thrust of involving individual or group of students in the process.
Creating an attractive and effective atmosphere in teaching language as what students' interest and need in learning has been done by many education practitioners in Indonesia. In the context of learning in higher education, especially in learning English, student-centered learning is also encouraged to make students actively involved in. Many learning methods and strategies are used and developed to improve students' language skills. Learning by group or collaborating with peers continues to be encouraged to achieve goals to meet an ideal target.

In learning English, among four language skills; listening, reading, speaking, and writing, the latter skill is considered to be one of the most difficult language skills. Students are still having difficulty in producing a work that is effective and good especially in other languages in this case English. Therefore, teachers of English as a Foreign Language (EFL) must remain focused and continuously develop students' writing skills to achieve better results.

In Indonesia, it must be admitted that writing has not been promoted as a sustainable activity. Compared with other countries, in terms of EFL higher education context, especially in Asia region; in China, for example, Lo and Hyland (2007) state that writing activities have focused on achieving good grades in the examination and accuracy of grammar. In Korea, Yanghee \& Jiyoung (2005) claim that writing activities are mainly concerned with the knowledge about the structure of language and overemphasis on the final products. Meanwhile, in Indonesia, a common practice that occurs in the context of EFL higher education is that there is an overlap between two subjects, namely writing and academic writing subject, specifically, in term of their contents, where in writing subject, it is mostly concerned with general writing skills, such as how to write topic sentences, supporting sentences and a concluding sentence, and includes an introduction to other types of writing genres in English. It does not emphasis a critical thinking as one of the characteristics of academic writing skills (Jubhari, 2009).

In the domain of ESL/EFL writing instruction, there is a growing interest in collaborative learning, which usually takes place within the context of writing groups, that is, small groups of students working together on a writing task. This normally occurs in the form of peer review situations in which students, working in groups, offer authentic audience feedback from which they learn to revise their papers. Writing groups are usually structured to focus group attention on 
individual writing, rather than on a single project that has been negotiated and enacted by and for the group.

Collaborative writing and evaluation of the articles produced are elements of authorship. Writing with another person or a group of people can make the challenge of producing a manuscript, a poster, a presentation, policies and procedures, or instructions for using a new piece of or equipment less daunting. However, with any partnership comes the responsibility to fulfill one's obligations in the process. Many researches with diverse areas and topics (e.g. school, workplace, genre, cultural background, educational background, etc.) have been done to prove the effectiveness of collaborative writing. In accordance to the benefits of collaborative writing toward adolescent and higher education students, it affords many usefulness, as expanding social interaction (Hirvela, 1999), contributing to a better quality of writing (Storch, 2011), producing a better sense of students (Leki, 1993), increasing motivation as well as increasing students' understanding on grammar and vocabulary usage (Swain \&Lapkin, 1998), and building up the abilities of collaboration and negotiation (Yang, 2014), and developing performance and achievement in writing.

In relation to the students' writing achievement which becomes one of the variables in this study, the researcher finds a fact in his observation in English Department of Mataram State Islamic University (in Indonesian context, it is familiarly called UIN Mataram) that the students still have a problem with their writing, especially in the process of writing, where the students still don't know how to write well. Indeed, the students find difficulties in almost all aspects of five component areas of writing that include content, organization, grammar, vocabulary, and mechanics. This condition makes the students' achievement is under the ideal target and far from the expectation.

Drawing on the foregoing rationales, the current study aimed to provide empirical evidence on the efficacy of collaborative writing strategy in an Indonesian EFL writing classroom. The following research questions guide this study:

1. To what extent did collaborative writing strategy influence students' writing achievement?

2. How did the students perceive about collaborative writing?

\section{LITERATURE REVIEW}

\section{Theoretical Framework}

Collaborative writing is the joint production of a text by two or more writers (Storch, 2011). In a line Ede \& Lunsford (1990) define collaborative writing as any writing done in collaboration with one or more persons. Collaborative writing means that the student teams up with one or more peers to go through the writing process; and collaborative writing in class is a way to prepare students for future assignments where team abilities are required (Ortiz \& Luna, 2013). Collaborative writing offers opportunities not only to practice literature review, academic reading and writing, but also to stimulate reflection, knowledge sharing, and critical thinking (Hadjerrouit, 2011).

Collaborative writing as a social interaction can be traced back to the social constructivist of Lev Vygotsky's (1978) and his seminal concepts of the zone of proximal development, scaffolding and intersubjectivity. Vygotsky defines the zone of proximal development as the distance between the actual developmental level as determined by independent problem solving and the level of potential development as determined through problem solving under adult guidance or in collaboration with more capable peers (Vygotsky, 1978). Stated differently, it is the difference between a learner trying to understand a new concept alone as opposed to learning it with the help of a teacher or fellow students. Scaffolding involves giving learners a great deal of support initially and then encouraged to become more independent and responsible for their learning as soon as possible (Stacey, 2005). Inter subjectivity has been described as the understanding achieved when people work together to co-construct resolution of a problem (Conrad, 2009).

The notion of social interaction for collaborative writing has been strengthened by some views of scholars. Colen\&Petelin (2004) state that collaborative writing is inherently a social interaction where learners can reach a consensus. They argue that collaborative writing is a production of a shared document, substantive interaction among members, and shared decision-making power over the document. Hirvela (1999) asserts that by giving this socially oriented view of writing, it would seem to make sense to create more classroom conditions in which students engage directly and productively in dialogue with peers. Through their creation of writing groups and various group-oriented activities, writing teachers would enable students to function simultaneously as writers and audiences within authentic communicative contexts.

Swain (2000) subsequent work expanded on the advantages of collaborative writing, specifically in her writing on collaborative dialogue and languaging. Collaborative dialogue (Swain, 2000) is defined as the talk that emerges when learners engage in a problem-solving activity. Swain perceives languaging as the process of using language in an attempt to make meaning; that is, it is a means through which thinking is articulated and thus brought into existence. When engaged in writing, learnerslanguage about language; that is, they deliberate about how to best express their intended meaning. Although languaging can occur with oneself, when one is composing individually, such languaging is usually sub-vocal (thinking), which is speech directed to oneself. The benefit of collaborative writing is that it encourages otherdirected talk, that is, talk that is vocalized. Once thoughts are vocalized, they are transformed into artefacts. These artefacts, together with the written text, can be further explored, that is, languaged further. Kelly et al. (2004) explain the strengths of collaborative writing, where they state that it helps learners to 
combine their strengths rather than focus on their weaknesses. A supportive and co-operative group can provide a safe audience that gives learners the security to take risks with their writing. It provides an immediate audience and feedback which helps learners become aware of the need for clear messages. It can provide opportunity for the 'dialogue' that single authors have to create for themselves. It helps learners to anticipate the potential reader's responses. It can make the process of revision more meaningful. It can help to empower learners. It can promote learner autonomy.

In collaborative Writing, the teacher or lecturer is not the center of the classroom any more. What teachers must do is just to help students become autonomous learners (Horwitz et al, 1997). Learning must be shared between the teacher and the learner or among learners with the guidance of the teacher. In teacher-student collaboration, teachers help learners work in groups effectively and teachers act as a part of each group too. Being a part of each group does not mean that teachers share equal power with group members. They just become a member of the groups as a guide and a facilitator whenever any group needs help. Teachers cannot share equal power in groups in collaborative learning because there are several groups in a classroom and each group might need help. In student-student collaboration, teachers are not participants in the collaborative work. They might only guide and facilitate the work whenever learners need help. The role of learners here is to negotiate with group members and to help to direct and reflect upon his or her own learning experiences (Wilhelm, 1997). There must be negotiation, interaction, help, and sharing in teacher-student or student-student collaborative work.

According to Louth, McAllister, \& McAllister (1993), there are two kinds of collaborative writing: interactive writing and group writing. In interactive writing, group members interact with each other during the different stages of the writing process. However, individual authors are ultimately responsible for their own work. Peer editing is an example of interactive writing. In group writing, group members also interact during the various stages of the writing process, but they are responsible for the final product. Coauthoring a report is an example of group writing. In a larger and more expansive manner, Farkas (1991) classifies four types of collaborative writing. First, two or more people jointly complete the whole text of a document. An example of this type of collaborative writing is coauthoring a report. Second, two or more people contribute components to a document. Writing separate parts of a text is an example of the second type of collaborative writing. Third, one person or more people edit or review the written work of one or more people. Peer feedback or peer editing is the typical example of this type of collaborative writing. Fourth, one person works with one or more people and drafts documents according to the ideas of the person or people. Group brainstorming is an example of this type of collaborative writing.

\section{Previous Studies on the Use of Collaborative Writing Strategy}

Storch (1999) conducted a study in which eleven intermediate to advanced adult ESL learners engaged twice in a series of grammar-focused writing tasks (a cloze exercise, text reconstruction, and composition): the first version was completed individually and the other version was done in pairs (or small groups). Storch found that collaborative writing and the LREs it generated had a positive effect on overall grammatical accuracy. Of particular interest, with regard to the composition, those texts written in pairs demonstrated a lower average number of errors than did compositions written individually (7.75 vs. 13.6) and a greater proportion of error-free clauses (61\% vs. $47 \%)$. She indicated that pairs spent more time on task as they attempted to solve the problems, which resulted in more accurate performances. Storch (2005) compared the compositions produced by pairs (9 pairs) with those produced independently (5 individuals). She found that pairs produced shorter but more superior texts in terms of task fulfilment, grammatical accuracy, and complexity, suggesting that pairs seemed to carry out the task more competently than did students writing individually. Storch concluded that collaboration afforded students the opportunity to pool ideas and provide each other with feedback.

In a similar but larger scale study, Storch and Wigglesworth (2007) compared the writing produced by learners working in pairs and individually. Postgraduate students who were advanced level ESL learners engaged in two composition tasks (a report task based on a visual prompt and an argumentative essay) either writing collaboratively (48 participants, 24 pairs) or in a solitary (24 participants) condition. The researchers analysed the participants' writing in terms of accuracy measured in global units: error free $\mathrm{T}$ units and error free clauses. Like Storch (2005), the researchers found that although no differences appeared in terms of fluency and complexity, pairs tended to produce texts with greater accuracy than individual writers.

Dobao (2012) investigated the effects of the number of participants in a writing task and the accuracy, fluency, and complexity of the texts produced in intermediate-level Spanish as a FL classes. She compared the performance of three writing conditions: groups of four learners (15 groups), pairs (15 pairs), and independent writing (21 individuals) as they engaged in a picture narration jigsaw task. The comparison of LREs between the groups versus pairs revealed that groups produced more LREs and correctly resolved more LREs than did pairs. Consequently, the analysis of the writing produced demonstrated that the texts written by the groups were more accurate than those written individually and in pairs. Like Storch and her colleagues (Storch, 2005; Storch\& Wigglesworth, 2007; Wigglesworth \& Storch, 2009), no differences were found in terms of syntactic and lexical complexity among the three conditions. 
Unlike the above mentioned researchers who collected and analysed data from a single writing session, Shehadeh (2011) conducted a longitudinal investigation into the effectiveness of collaborative writing on L2 writing. The analysis revealed that collaborative writing had significant effects on content, organization, and vocabulary but not for grammar or mechanics.

\section{RESEARCH METHOD}

\section{Research Design}

This research was a mixed-method, which combined both qualitative and quantitative approaches by essentially mixing both quantitative and qualitative method in a single study, during the data collection and data analysis phases of the study (Gay \& Airasian, 2006; Saleh et al., 2021; Mustaret., 2021). To explore the first research question, a quasiexperimental design was applied, in which two groups of students were involved (Hasyim et al., 2021). In this study, only two classes were assigned to be the participants of the present study. Finally, the second research question was dealt with by employing a descriptive-qualitative procedure to examine the responses to the questionnaire.

\section{Participants of the Study}

In this study, the participants were the students of classes A and B of the third grade of the Englishdepartment of UIN Mataram. Each class had 32 students. The researcher chose this class due to the findings in the pre-observation. The researcher found that the students in both classes had the lowest degree of achievement in writing compared to the students of the three other classes (C, D, and E classes). In addition, as the nature of experimental design of this study, where it employed quasi-experimental design, the researcher had a right to not choose the group of students randomly. The researcher assigned two classes or groups as the participants. In this case, the researcher chose classes A and B.

There were two research instruments used in this study. They were awriting test, and interview questionnaire (Hasyim et al., 2021). To know the influence and improvement of students' writing achievement. The researcher did pre-test and post-test. Both of the tests were undertaken before and after the treatment. In this case, the researcher used the essay writing test that contained a set of instruction to be done by the students.

Table 1:The Writing Prompts of Pre-test and Post-testby Instruction and Topic

\begin{tabular}{|c|c|}
\hline Instruction & Topic \\
\hline $\begin{array}{c}\text { Write in English about } \\
\text { the following topic. } \\
\text { You will have only 90 } \\
\text { minutes to finish your } \\
\text { writing. You may } \\
\text { facilitate your-self with } \\
\text { a dictionary. Some } \\
\text { vocabularies will be } \\
\text { provided to help you to } \\
\text { complete your essay } \\
\text { successfully. }\end{array}$ & $\begin{array}{c}\text { The advantages and disadvantages of tourism } \\
\text { indery following words may help you in }\end{array}$ \\
\cline { 2 - 2 } & Incomeriting your essay: \\
\hline
\end{tabular}

Meanwhile, regarding the questionnaire, there were seven questions or items devised for the interview intended to investigate the students' perceptions regarding the use of collaborative writing strategy.

\section{The Procedure of the Study}

There were seven phases employed in this study. The first one was the preliminary phase. This part elaborated the stages of preparation of the study before collecting the data. In this phase, instruments (writing achievement test items, and interview guide) were organized, lesson plans were created to be guidance during the application of the treatment, materials were prepared to support the treatment, and the students were assigned to the control and experimental groups. The second phase involved preparing the research instruments. There were two kinds of instruments prepared in this study; writing achievement test, and semi-structure interview guide. The items of the writing achievement test included a brief and detailed instruction that was stated descriptively in written form. As well as in the writing achievement test, semistructure interview contained a brief and detailed instruction. Third phase focused on preparing lesson plan and materials. The next step was arranging lesson plans for both experimental and control groups. Six lesson plans were prepared for each group as there were six sessions of teaching for each group (giving collaborative writing treatment to the experimental group and conventional treatment or individual writing to the control group). Not only lesson plans but also learning materials were prepared to support the teachinglearning processes. They included; handouts, special written instructions, essay model text to be acknowledged while they were learning the essay writing texts, and charts for the ice breaking stage in the teaching process to help the students focus on the topic to be introduced. These materials were developed in accordance with the nature of the collaborative writing (for the experimental group) and the teaching strategies that were usually applied by the lecturer (for the control group). The Fourth phase dealt with assigning students to the control and experimental groups. Students, as the participants or the sample of the study were treated differently according to which group they belonged to. The student grouping was organized by considering what was going on in the campus academic environment. The English lecturer of the third-grade students assigned two classes out of five classes to be involved in this study. The choice of the two groups was based mainly on the learning schedule of those two groups so that the learning environment was not interrupted in terms of schedule. One of the two learning groups was later assigned as the experimental group and the other was as the control group. Fifth phase focused on administering the pre-test. In this phase, the two groups were directed to have the pre-test. The Sixth phase was considered as the main phase. Teaching essay writing text was the main phase of this study. In other words, the main phase of this study was the process of giving the treatment by using the collaborative writing strategy. According to the plan that had 
been made, there were six sessions for each group in this phase. Every session will be lasted for $2 \times 60$ minutes. The seventh phase happened to be the last or the closing phase. After the two groups of students were involved in the teaching-learning processes, they were directed to have a posttest for essay writing test in which the items were the same to those that had been used in the pre-test. The purpose of doing this was to measure the achievement, whether or not there was a progress in the students' writing achievement after being taught using different treatments. During this closing phase, a semi-structure interview was also done to the participants in order to gain the data regarding the students' perception towards collaborative writing strategy. This was only available for the experimental group because the control group had not experienced yet with this strategy. After all of the data were obtained, the next step was analyzing the data.

\section{FINDINGS}

The Influence of the Collaborative and Individual Writing towards Students' Writing Achievement

After all of the instruction had been finished, the post-test was undertaken to both groups. The time allocation for completing their test was approximately 90 minutes. The same topic was given to the both groups. The topic entitled; 'The advantages and disadvantages of tourism industry for local people in West Nusa Tenggara.' The results of the two groups post-test are figured out in the following tables:

Table 2: T-test Result of Experimental and Control Groups' Post-test

\begin{tabular}{|c|c|c|c|c|c|}
\hline & Groups & $\mathrm{N}$ & Mean & $\begin{array}{c}\text { Std. } \\
\text { Deviation }\end{array}$ & $\begin{array}{c}\text { Std. } \\
\text { Error } \\
\text { Mean }\end{array}$ \\
\hline \multirow{2}{*}{ Score } & $\begin{array}{c}\text { Experimental } \\
\text { Group }\end{array}$ & 32 & 7.1432 & .57198 & .10111 \\
\cline { 2 - 6 } & $\begin{array}{c}\text { Control } \\
\text { Group }\end{array}$ & 32 & 6.4609 & .53631 & .09481 \\
\hline
\end{tabular}

Table 3: Independent Samples Test of the Experimental and Control Groups Post-Test

\begin{tabular}{|c|c|c|c|c|c|c|c|c|c|c|}
\hline & \multicolumn{2}{|c|}{$\begin{array}{c}\text { Levene's Test for } \\
\text { Equality of Variances }\end{array}$} & \multicolumn{7}{|c|}{ t-test for Equality of Means } & \\
\hline & & \multirow{2}{*}{$\mathrm{F}$} & \multirow{2}{*}{ Sig. } & \multirow{2}{*}{$\mathrm{T}$} & \multirow{2}{*}{ Df } & \multirow{2}{*}{$\begin{array}{l}\text { Sig. }(2- \\
\text { tailed) }\end{array}$} & \multirow{2}{*}{$\begin{array}{c}\text { Mean } \\
\text { Difference }\end{array}$} & \multirow{2}{*}{$\begin{array}{l}\text { Std. Error } \\
\text { Difference }\end{array}$} & \multicolumn{2}{|c|}{$\begin{array}{l}\text { 95\% Confidence Interval of the } \\
\text { Difference }\end{array}$} \\
\hline & & & & & & & & & Lower & Upper \\
\hline \multirow{2}{*}{ Score } & $\begin{array}{c}\text { Equal } \\
\text { variances } \\
\text { assumed }\end{array}$ & .108 & .743 & 4.922 & 62 & .000 & .68229 & .13861 & .40522 & .95937 \\
\hline & $\begin{array}{c}\text { Equal } \\
\text { variances not } \\
\text { assumed }\end{array}$ & & & 4.922 & $\begin{array}{c}61.7 \\
45\end{array}$ & .000 & 68229 & .13861 & .40519 & .95939 \\
\hline
\end{tabular}

Table 4: Descriptive Statistics of the Total and the Componential Scores in the Post-test of Writing

\begin{tabular}{|c|c|c|c|c|c|c|c|c|}
\hline & \multicolumn{4}{|c|}{ Experimental Group } & \multicolumn{4}{|c|}{ Control Group } \\
\hline & \multicolumn{3}{|c|}{ Post-test } & \multirow[b]{2}{*}{ Min Score } & \multicolumn{3}{|c|}{ Post-test } & \multirow[b]{2}{*}{ Min Score } \\
\hline & $\begin{array}{l}\text { Max } \\
\text { Score }\end{array}$ & M & SD & & $\begin{array}{l}\text { Max } \\
\text { Score }\end{array}$ & M & SD & \\
\hline Organization & 8 & 7.20 & 0.620346 & 6 & 8 & 6.71 & 0.694883 & 5 \\
\hline Developmental & 8.5 & 7.10 & 0.78014 & 4.5 & 7.5 & 6.34 & 0.614837 & 5.5 \\
\hline Cohesion & 8 & 7.10 & 0.737633 & 5.5 & 8 & 6.45 & 0.699762 & 5 \\
\hline Structure & 8.5 & 7.17 & 0.799288 & 5 & 8 & 6.43 & 0.820602 & 5 \\
\hline Vocabulary & 8 & 7 & 0.672022 & 5.5 & 7.5 & 6.42 & 0.730768 & 5 \\
\hline Mechanics & 9 & 7.26 & 0.695427 & 6 & 8 & 6.39 & 0.680777 & 5 \\
\hline
\end{tabular}




\section{Students' Perceptions on the use of the Collaborative Writing Strategy}

Table 5: Summary of the Students' Perceptions on the Use of Collaborative Writing

\begin{tabular}{|c|c|}
\hline Questions & Students' Sample Excerpts \\
\hline $\begin{array}{l}\text { Have you done a } \\
\text { similar activity of } \\
\text { writing in a group } \\
\text { before? }\end{array}$ & $\begin{array}{l}\text { "I have never learned in a group in the writing class before" } \\
\text { "No, my lecturer just taught us using a conventional technique, where we were given a topic and we as students wrote an essay } \\
\text { based on the lecturer's instruction" } \\
\text { "No, I have never done it yet" }\end{array}$ \\
\hline $\begin{array}{l}\text { How do you feel and } \\
\text { what do you think about } \\
\text { your writing after being } \\
\text { taught by using } \\
\text { collaborative writing } \\
\text { strategy? }\end{array}$ & $\begin{array}{l}\text { "I feel working in a group as what we have done in collaborative writing recently increases my motivation to study English } \\
\text { more. I get so many experiences on it. I tend to believe my own ability rather than asking my friend over and over. Onward, I } \\
\text { believe that my writing will be better" } \\
\text { "Working in a group for me is very interesting. We can share ideas, experiences, and knowledge together. We respect each other } \\
\text { as partners. If there any problems found, we solve them together. We directly can give input for the best choices as the answers. } \\
\text { Face to face interaction that happens in the collaborative writing might expose our strengths and weaknesses; this can be a self- } \\
\text { evaluation for us. In relation to my writing, I think I am more and more competent now than before. } \\
\text { "My writing is getting better and better time by time. My weakness in writing is in the time management, but after his } \\
\text { involvement in the collaborative writing, I fell that I can manage my time well. Frankly speaking that I do not like working in } \\
\text { group. I prefer to write individually to work in group.. when I work alone, I can genuinely express my idea freely. I fell that the } \\
\text { final product of my group do not belong to me." }\end{array}$ \\
\hline $\begin{array}{l}\text { What are positive } \\
\text { aspects of collaborative } \\
\text { writing do you get? }\end{array}$ & $\begin{array}{l}\text { "There are many things I can get from working collaboratively, at first, I think writing is something difficult for me, but when } \\
\text { working in group, I felt it just fun and easier. I felt less stressful than writing alone. There would be many friends who help me } \\
\text { when I found any difficulty in English it then increases my motivation in Learning English" } \\
\text { "I can share a mutual feed back with my group members; we can share important information, ideas, and opinions that I cannot } \\
\text { do when I work alone or individually. We also learn to respect each other. When we have mistakes in grammar, vocabulary, and } \\
\text { other language components, we correct them together" }\end{array}$ \\
\hline $\begin{array}{l}\text { How do you contribute } \\
\text { in your group when } \\
\text { working } \\
\text { collaboratively? }\end{array}$ & $\begin{array}{l}\text { "I don't know what is actually my contribution to my group. I just follow the rules and the steps of the writing process. If my } \\
\text { leader asks me to find difficult words, then I'll look up my dictionary. Nevertheless, I still do what my partners do. It up to my } \\
\text { friends' decision whether they want to use a part of my work or not" } \\
\text { "Everybody in my group give the same contribution as their own roles. We work together to make a final results of writing" }\end{array}$ \\
\hline
\end{tabular}

\section{DISCUSSION}

\section{The Influence of the Collaborative and Individual Writing towards Students' Writing Achievement}

Drawing on the descriptive statistics of the data, it revealed that at the initial standing point, the mean scores of both experimental and control groups' pre-test were in the same baseline or level. Even though the mean score of experimental group $(\mathrm{M}=6.35)$ was higher than that of control group $(\mathrm{M}=6.09)$, however, when confirming to independent sample t-test, the difference did not contribute much in terms of significance. In other words, it can be construed that there was no significant difference between the two groups. The evidence exposed a factual point corresponding to the essay scoring rubric proposed by Paulus (1999) as the basis of assessing the students' writing, the students in the two groups were categorized as in scale 6 . After providing the two groups with different treatments over eight meetings for each, at the end of the instruction, the difference of the two groups was visible where the experimental group changed into scale 7 and the control group was still remaining at scale 6 . To investigate this claim, an independent sample t-test was run. The results 
confirmed that there was a difference of the experimental and control groups' mean scores of their post-test. The experimental group's mean score $(\mathrm{M}=7.14)(\mathrm{SD}=0.57)$ was greater than that of control group's mean score (6.45) $(\mathrm{SD}=0.53)$. The difference of the two mean scores was 0.58 . It also unveiled that their sig. (2-tailed) (0.00) was lower than (0.05). This statistical evidence confirmed that there was a significant difference between the students who employed CW than those who performed individually. The findings aforementioned were also strengthened by the statistical analysis of the six componential areas of writing of the two groups. It displayed that the scores obtained by experimental group outperformed the control group in all aspect areas of writing as it was figured out, where, the mean score of the organization component was $7.20 \quad(\mathrm{SD}=.62)$ for the experimental group and $6.71(\mathrm{SD}=.69)$ for the control group, the mean score of the developmental component was 7.10 $(\mathrm{SD}=.78)$ for the experimental group and $6.34(\mathrm{SD}=.61)$ for the control group, the mean score of the cohesion component was $7.10(\mathrm{SD}=.73)$ for the experimental group and 6.45 $(\mathrm{SD}=.69)$ for the control group, the mean score of the structure component was $7.17(\mathrm{SD}=.79)$ for the experimental group and $6.43(\mathrm{SD}=.82)$ for the control group, the mean score of the vocabulary component was $7(\mathrm{SD}=.67)$ for the experimental group and $6.42(\mathrm{SD}=.73)$ for the control group, and the mean score of the mechanics component was 7.26 $(\mathrm{SD}=.69)$ for the experimental group and $6.39(\mathrm{SD}=.68)$ for the control group. The aforementioned data once again indicated that the experimental group was powerful than that of control groups in the six componential areas of writing.

The findings of this study are in harmony to some previous studies Dobao, 2012; Shehadeh, 2011; Storch, 2005; Storch\& Wigglesworth, 2007; Watanabe, 2014). Even though the findings of this study are compatible with those previous studies in general, however, with respect to 'grammar' as one of specific areas of writing components, the findings on this specific area are in conflict with those of Shehadeh's whereby grammar component does not improve significantly compared to other areas. He claims that the use of different measures of grammatical accuracy are the reason behind the disharmony of his finding compared to others. In respect to this case, Watanabe (2014:127-129) gives a broader explanation of the possible reasons for the discrepancies of the studies of this area: a) different and imprecise measurement instruments; b) different time periods on writing tasks, and c) different student populations and educational contexts.

Anchored in the social constructivist theory, collaborative writing provides the learners to engage in meaningful and purposeful communication. When the students collaborate their knowledge in communication, it makes a meaningful communication (Khatib\&Melhami, 2015). While writing a topic, the students work collaboratively with the same needs. In this occasion, the students' lack in some areas of writing is fulfilled by other students who are more competent in the specific areas of writing. When the needs are fulfilled their cognitive process start to react toward the newly obtained materials and finally learning happens (Storch, 2005). Nixon (2007) asserts that the process that happens in the collaboration is more effective and beneficial for low English proficiency learners than for high English proficiency learners. According to zone of proximal development (ZPD) theory, advanced individuals can scaffold, develop and create an inner voice in other individuals who are not so advanced (Vanderburg, 2006). The 'expert' students provide the assistance for the 'novice' students to go through beyond their current level to the higher potential level.

\section{Students' Perceptions on the Use of the Collaborative Writing Strategy}

As stated earlier, in order to answer the second research question, the four students with a varied proficiency were interviewed immediately after the post test. The students were chosen to represent the whole population. The seven questions devised for the interview intended to investigate the students' perceptions or opinions regarding the use of collaborative writing strategy. The results are summarized and interpreted as follows:

Question number 1 investigated whether all the students had the same background knowledge and condition before getting involved in the collaborative writing instruction. At the initial condition, all students had the same experiences that they were not accustomed to using $\mathrm{CW}$ at their previous learning in terms of teaching of writing. For instance, student A said, I have never learned in a group in the writing class before." Meanwhile, students B and C said that they had just been taught using conventional technique before in their writing class. Student D asserted that he ever used the similar technique but, it was not in the writing class. The students' answer towards the given question gave an indication that all the students had not experienced yet and were not familiar with the collaborative writing strategy.

Asked concerning their feelings and what they about their writing after being taught using CW, all students' responses were positive towards the application of $\mathrm{CW}$. They felt that their English increased and became better over time. Yet, CW gave a special impact on their motivation and their social interaction as stated by student $\mathrm{C}$ that by working in a group, he could share ideas, experiences, and knowledge together with the other students and they respected each other as partners. If there were any problems encountered, he and his groups' member solved them together. In addition, he affirmed that face- to- face interaction that happened in the collaborative writing might expose his strengths and weaknesses. Students' answers corroborated the opinions of students from the previous studies (e.g., Nixon (2007); Shehadeh (2011); Storch (2005), Watanabe (2014)) that they perceived positive responses from writing in groups thereby confirming some benefits of collaborative writing.

With respect to the question number three, it was surprisingly found that the students had varied answers. Students A and B 
a low proficiency in English preferred collaborative way in writing. Student C preference was based on the writing genres. Thus he might work collaboratively or individually, it was a conditional. Meanwhile, student $\mathrm{D}$ as the most proficient student, preferred to write alone or individually. This phenomenon implied that the students with the low proficiency (novice) needed more help and assistance from the expert students. This supports and accords the Vygotsky concept of the ZPD. It emerged that the novice, the low, the less proficient students, needed help from the expert. This is in line with Gabriel \&Leeuwen's (2007) view that the effect of using more advanced peers to improve less advanced students was better than having students collaborate with each other.

In respect of the positive aspects of collaborative writing, it drew on multiple students' responses. All students perceived positive responses as it increased students' motivation and confidence, reduced stressful, gave new horizon on the way of how students to write, shared mutual feedback, gave a good attitude to respect each other, and knew others characters. The findings were in line with Watanabe's (2014) findings, where the students' interview responses in her study focused on six perceived benefits of collaborative writing; opportunities for new learning, mutual feedback, enjoyable experiences, increased motivation, less stress and opportunities to get to know others. The empirical evidence of this study also parallels to Shehadeh's (2011) findings that CW enhanced not only students' self-confidence and their writing ability, but their other skills as well, in particular their writing skills. He also unveiled that $\mathrm{CW}$ activity enabled students to generate ideas, pool ideas together, discuss and plan, generate their text collaboratively, provide each other with immediate feedback, and put their text in better shape. In addition, Storch (2005) advocated that collaboration that happens in the $\mathrm{CW}$ afforded students the opportunity to pool ideas and provide each other with feedback.

In relation to the negative sides of $\mathrm{CW}$, some problems occurred within the application of CW towards students' feelings. Firstly, some students felt that working in groups was time-consuming, especially in the process of negotiating the ideas; which was better to be chosen. As stated by student $\mathrm{C}$, "it's quite difficult for the group to find out which one of the ideas, vocabularies, appropriate grammar, etc. should be chosen. It needed much time to discuss them." Secondly, there was a competition among partners of the groups. This occurrence sometimes made the students feel reluctant to engage seriously in their discussion. Once the low proficiency students made a mistake, they would feel that they lost their faces among their group's members. The concern about hurting the feelings of others was also noted in other researches (see Storch, 2005; Nelson \& Carson, 1998). Thirdly, there was a feeling of being bothered especially for those who were chosen to be 'leader' or 'Expert' in the groups. They vividly worked hard to consolidate, manage, compose, and lead their groups. Due to the fact that their proficiencies were better than other students, they felt exhausted to hold a bigger responsibility. This made them feel stressed and depressed. The findings of the students' feeling towards the negative sides of $\mathrm{CW}$ were in the same vein with Watanabe's (2014) findings that the challenges of collaborative writing involved; the difficulty of negotiating ideas, time consuming activities, lack of freedom, familiarity with writing independently, and feeling pressure of oversensitivity.

With respect to the students' contribution in their groups, it is worth mentioning that each student had their own roles in their groups depending on their level of proficiencies. For example, the student $\mathrm{A}$ as the lowest proficient student tended to follow the rule of his group. He felt that he needed to be helped and scaffolded by the expert students. Meanwhile, students B and C affirmed that they had the same roles in their groups; their pieces of work contributed over forming the final results of the groups' writing. Student D, as the most proficient student. felt that he contributed a lot in his group, where he constructed the final results of his group. Anyhow, he also admitted that a myriad contribution of his group's members over the discussion was being held. The findings indicated that the expert students had a more difficult task in their group compared to novice students. The expert students helped, scaffolded, and led their groups. The findings of this study support Vygotsky's theory which says that students can only perform tasks individually if they first collaborate with more capable people who can scaffold them (Vygotsky, 1978:86).

In regard to the last question, it was found that selecting and choosing the appropriate words were the most dominant problems encountered by the students, followed by the process of translating and transferring the knowledge from L1 to L2. In addition, managing the time and condition was also affirmed as the students' problems. In the process of transferring knowledge from L1 to L2, first, the students construct the knowledge as joint activity, then, process it into mental process; the approximation and internalization (Shehadeh, 2011: 297). This means that through the process, the students can create a meaningful communication as a source of L2 learning.

\section{CONCLUSION AND IMPLICATION}

Two major findings emerged from the study. Firstly, it revealed that there was a difference of the experimental and control groups' mean scores of their post-test. The experimental group's mean score $(\mathrm{M}=7.14)(\mathrm{SD}=0.57)$ was greater than that of control group's mean score (6.45) $(\mathrm{SD}=0.53)$. The difference of the two mean scores was 0.58 . Seen from its independent sample test, it also unveiled that their sig. (2-tailed) (0.00) was lower than (0.05). This statistical evidence exhibited that there was a significant difference between the students who employed collaborative writing strategy than those who did not employ it. Secondly, all students' responses were positive towards the application 
of collaborative writing strategy as it increased students' motivation and confidence, reduced stress, gave new horizon on the way of how students to write, shared mutual feedback, gave a good attitude to respect each other, and knew others characters. The findings of the study give some implications. First, the use of the collaborative writing strategy influences the students' writing achievement. It implies that the strategy would be very helpful for the lecturer to improve the students' understanding on their writing, especially in essay writing. Secondly, this strategy can be a direction for the English lecturers to design an effective teaching strategy of writing by integrating the steps of the strategy in the syllabus and lesson plan.

\section{REFERENCES}

[1] Colen, K. \&Petelin, R. (2004). Challenges in collaborative writing in the contemporary corporation. Corporate Communications: An International Journal. 9 (2), 136-145.

[2] Conrad, R. (2009). Assessing collaborative learning. In P. L. Rogers, G. A. Berg, J. V. Boettecher, C. Howard, L. Justice, \& K. Schenk (Eds.), Encyclopedia of Distance Learning, Second Edition 2nd ed., 89-93. Hershey PA: Information Science Reference.

[3] Dobao, A., F. (2012). Collaborative writing tasks in the L2 classroom: Comparing group, pair, and individual work. Journal of second language writing. 21(1), 40-58.
[4] Farkas, D. K. (1991). Collaborative writing, software development, and the universe of collaborative activity. In M. M. Lay \& W. M. Karis (Eds.), Collaborative writing in industry: Investigations in theory and practice (pp. 13-30). Amityville, NY: Baywood Publishing Co.

[5] Gabriel, M. \&Leeuwen, C., A. (2007). Beginning to write with word processing: Integrating writing process and technology in a primary classroom. The reading teacher. 60 (5), 420-429.

[6] Gay, L. R., Mills, G. E. \&Airasian, P. W. (2006). Competencies for analysis and application, $10^{\text {th }}$ ed. New York: Pearson.

[7] Hadjerrouit, S. (2011). A Collaborative Writing Approach to Wikis: Design, Implementation, and Evaluation. Issues in Informing Science and Information Technology. 8, 431-449.

[8] Harmer, J. (2003). The practice of English language teaching. London: Longman.

[9] Hasyim, M., Latjuba, A.Y., Akhmar, A.M., Kaharuddin, Saleh, N.J. (2021). Human-Robots And Google Translate: A Case Study Of Translation Accuracy In Translating French-Indonesian Culinary Texts. Turkish Journal of Computer and Mathematics Education, 12 (4), 1194- 1202.

[10] Hasyim, M., Arafah, B., Fatimah, Saleh, F. (2021). Female Sexuality For Male: The Power Relation Of Women in The Intimacy Relationship Of The Partner On Tv Advertisements, A Semiotic Analysis. Turkish Journal of Physiotherapy and Rehabilitation, 32(3), 79-87.

[11] Hirvela, A. (1999). Collaborative writing instruction and communities of readers and writers. TESOL Journal, 8, 7-13. 